PACS: $52.27 . \mathrm{Lw}$

\title{
MACROPARTICLE REFLECTION FROM A BIASED SUBSTRTATE IN PLASMA ION IMPLANTATION SYSTEMS
}

\author{
DElena V. Romashchenko*, (D)Aleksander A. Bizyukov, IIgor O. Girka \\ V. N. Karazin Kharkiv National University \\ Svobody sq., 4, 61022, Kharkiv, Ukraine \\ *Corresponding Author: ev.romashchenko@gmail.com \\ Received December 18, 2019; accepted January 20, 2020
}

\begin{abstract}
Generation of metal plasma in vacuum arc discharge is always accompanied by a production of macroparticles (MPs). The MP contamination in coatings is the most important technological problem in plasma immersion ion implantation (PIII). For the case of PIII with long pulse duration, the results of theoretical study of MP charging and dynamics in the plasma sheath are presented. To describe the MP charging in the sheath the sheath model is combined with orbital motion limited (OML) theory. The MP charging in the sheath is studied with taking into account emission processes from MP surface as well as kinetic electron emission (KEE) from the high voltage substrate. The charge and dynamics of MP are governed by local parameters of counter fluxes of ions and secondary electrons from the substrate. The MP charge depends on the MP local position within the sheath. The dominant role in MP charging is shown to be played by KEE from the substrate, which is an important feature of PIII. KEE from the substrate changes the potential profile within the sheath, the sheath thickness, and current balance on MP surface. MP charge is obtained to be negative because it is caused by higher current density of secondary electrons from the substrate than that of ions. The latter is possible for KEE yield larger than a unit. The substrate biasing influences both the release of secondary electrons from the substrate under ion impact and their acceleration in the sheath. The increasing of negative substrate bias is demonstrated to result in the increasing of absolute value of negative MP charge, and, thereby, the increasing of electrostatic reflection of MP from the substrate. The negative substrate biasing is shown to be the effective alternative method to reduce MP contaminations in coatings without applying any magnetic filters.
\end{abstract}

KEY WORDS: plasma immersion ion implantation, macroparticle, kinetic electron emission

Vacuum arc is known to provide a means for producing metal plasma for thin film deposition and ion implantation $[1,2]$. The favorable characteristic features of the vacuum arc metal plasma are the high ion flux, high ionization degree, and multiple ion charge [3-5]. Ion bombardment of a substrate surface changes its physical, electrical, and chemical properties. Substrate biasing is an established technique to control the ion bombardment energy. The amplitude of the bias is a key parameter, which results in a qualitatively different kind of surface modification. Low-energy ion bombardment with energies from several tens of electronvolts to several hundreds of electronvolts is used for thin film deposition. Plasma immersion ion implantation (PIII) is an effective surface modification technique. The typical bias in PIII belongs to the range from 1 to $100 \mathrm{kV}$, with the lower values for semiconductor applications and higher values for metallurgical applications [2]. Besides, the bias is usually pulsed to allow the plasma to replace depleted ions between the pulses.

The macroparticles (MPs) contamination in many PIII applications, particularly semiconductor applications, is the most important technological problem [6]. The MP size occurs in the range from fraction to tens microns. The incorporation of MPs into the coating degrades the quality of the films, e.g. produces surface roughening, protuberances, bumps and pinholes. The experimental observations reveal that the number of MPs can be reduced by substrate biasing [7]. We have recently considered the effect of negative substrate biasing on MP contamination in vacuum arc deposition (VAD) [8]. The energy of multiply charged ions at the substrate is increased by applying a negative bias. The multiply charged ions may cause a release of secondary electrons from the substrate surface. Secondary electron emission (SEE) occurs through two general processes, known as kinetic electron emission (KEE) and potential electron emission (PEE). Because of the relatively low kinetic energy of the ions (below $1 \mathrm{keV}$ ), only PEE is of importance in the VAD. In contrary to VAD, KEE is an important feature of PIII [9].

The aim of this work to study the effect of substrate biasing on MP contamination in ion implantation system with taking KEE into account.

\section{SHEATH MODEL FOR ION IMPLANTATION}

In PIII, the substrate is immersed into a vacuum arc produced plasma, and series of negative high-voltage pulses are applied to the substrate. Applying a high voltage negative bias to the substrate accelerates and implants the ions. A collisionless dynamic sheath model for implantation of singly charged ions has been introduced by Lieberman [10]. Later, this model has been extended to take the multiple charge state into account [11]. According to Lieberman model [10], when a high voltage pulse of amplitude $-V_{0}$ is applied, the electrons are driven away from the substrate region on a time scale of inverse electron plasma frequency $\omega_{p e}{ }^{-1}$. This time is very short, of about few nanoseconds. This leads, in turn, to production of a region of positive space charge known as the ion matrix sheath. Then, on the slower time scale of the order of inverse ion plasma frequency $\omega_{p i}{ }^{-1}$, the ions are accelerated toward the substrate by the electric field (c) Elena V. Romashchenko, Aleksander A. Bizyukov, Igor O. Girka, 2020 
inside the sheath and the ion current density reaches a maximum. Subsequently, the sheath edge expands outwards uncovering more ions until the end of the voltage pulse. The ion matrix sheath evolves into a quasi-static Child law sheath with time-varying current density [10]

$$
J_{C}=\frac{4}{9} \varepsilon_{0}\left(\frac{2 Z e}{m_{i}}\right)^{1 / 2} \frac{V_{0}^{3 / 2}}{s(t)^{2}},
$$

where $s$ is the sheath thickness, $m_{i}$ is the ion mass, $\varepsilon_{0}$ is the permittivity constant, $e$ is the elementary charge, $\mathrm{Z}$ is the ion charge state.

The sheath expansion velocity $s(t)$ is given by

$$
s(t)=s_{0}\left(1+\frac{2}{3} \omega_{p i} t\right)^{1 / 3},
$$

where

is the ion plasma frequency, and

$$
\omega_{p i}=\left(\frac{Z^{2} e^{2} n_{0}}{\varepsilon_{0} m_{i}}\right)^{1 / 2}
$$

$$
s_{0}=\left(\frac{2 \varepsilon_{0} V_{0}}{Z e n_{0}}\right)^{1 / 2}
$$

is the matrix sheath thickness.

In metal plasma produced by a vacuum arc, an equilibrium steady-state ion sheath can be formed $[13,14]$.

The steady-state Child law thickness, which is the maximum sheath thickness that can be reached, is [12]

$$
s_{\max }=s_{0}\left(\frac{2 u_{0}}{9 u_{B}}\right)^{1 / 2},
$$

where the characteristic ion velocity $u_{0}$ is

$$
u_{0}=\left(\frac{2 Z e V_{0}}{m_{i}}\right)^{1 / 2},
$$

the Bohm velocity $u_{B}$ is

$$
u_{B}=\left(\frac{Z k_{B} T_{e}}{m_{i}}\right)^{1 / 2},
$$

$k_{B}$ is the Boltzman constant, $T_{e}$ is the electron temperature.

The stationary Child law sheath is established for the time [6]

$$
t_{C}=\left(\frac{3}{2}\left(\frac{s_{\max }}{s_{0}}\right)^{3}-\frac{3}{2}\right) \omega_{p i}^{-1},
$$

and approximate expression for this time is

$$
t_{C} \approx \frac{\sqrt{2}}{9} \omega_{p i}^{-1}\left(\frac{2 Z e V_{0}}{k_{B} T_{e}}\right)^{3 / 4} .
$$

For example, for the magnitude $-2 \mathrm{kV}$ of the substrate bias, the sheath reaches its quasi-stationary position in metal plasma during about few $\mu$ s. Therefore, in the case of application of low implantation voltage and long pulse duration (in limiting case: DC), the steady-state sheath model can be considered.

The ions accelerated by electric field of the sheath deliver significant kinetic and potential energy to the substrate. The high kinetic energies make it possible for them to penetrate deeply into the surface, to change the atomic composition and structure in near-surface region of the target material, and, thereby, to change the properties of the surface material [12]. When ions impact the substrate with high energies, they cause the PEE and KEE from the substrate. The implantation current density is the sum of the ion current density $j_{i}$ and secondary electron current density $j_{s e}$

$$
j=j_{i}+j_{s e}=\left(1+\frac{\gamma}{Z}\right) j_{i} .
$$

Recognizing that there are two contributing process we can write the total SEE yield $\gamma$ as

$$
\gamma=\gamma_{p}+\gamma_{k},
$$

where $\gamma_{p}$ is the potential SEE yield, and $\gamma_{k}$ is the potential SEE yield. 
At high sheath voltages $(>1 \mathrm{kV})$, the electron emission mechanism is mainly determined by the kinetic energy of the arriving ions, and KEE becomes dominant. Therefore, the contribution to the total SEE yield by KEE is much larger than that by PEE, $\gamma \approx \gamma_{\mathrm{k}}$. The KEE yield $\gamma_{k}$ is proportional to the square root of the kinetic ion energy, which is, in turn, determined by the applied voltage $V_{0}, \gamma \sim\left(V_{0}\right)^{1 / 2}$.

In the coordinate system applied in the present paper, a plasma-sheath interface is taken to be the origin, $x=0$, and the position of the substrate is determined by the sheath thickness. The flux of secondary electrons is accelerated away from the substrate in the sheath electric field that accelerates the ion flux towards the substrate. To obtain the potential distribution $\Phi(x)$ within the sheath one has to consider both particle fluxes in Poisson's equation - to and from the substrate:

$$
\frac{d^{2} \Phi}{d x^{2}}=-\frac{e}{\varepsilon_{0}}\left[Z n_{i}-n_{s e}\right]
$$

where $n_{i}$ and $n_{e}$ are the ion and electron density, respectively.

The expressions for the densities of ions and secondary electrons can be obtained from the equations of continuity and energy conservation

and

$$
n_{i}=\frac{j_{i}}{e} \sqrt{\frac{m_{i}}{2\left(\varepsilon_{i o}-Z e \Phi\right)}},
$$

$$
n_{s e}=\frac{j_{s e}}{e} \sqrt{\frac{m_{e}}{2 e\left(\Phi-V_{0}\right)}},
$$

where $m_{e}$ is the electron mass, $\varepsilon_{i o}$ is the initial energy of ions.

The quasi-neutrality condition at the sheath edge is

where $n_{0}$ is the bulk plasma density.

$$
n_{0}=Z n_{i}(0)+n_{s e}(0)
$$

The Bohm criterion is oversatisfied at the sheath edge because of supersonic velocity of implanted metal ions. The boundary conditions for integration of Poisson's equation (11) are: $\Phi(0)=0 ; \mathrm{d} \Phi / \mathrm{dx}=0$. The potential variation in the sheath can be found numerically by integrating the Eq. (11). The MPs are assumed to have no effect on the sheath structure.

\section{MP CHARGING}

We consider the MP with the radius $a$ as a spherical probe immersed into the counter fluxes of ions and secondary electrons from the substrate. In addition, secondary electrons from MP surface can be produced by electron and by ion impacts.

The MP charge $Q$ is one of the most important characteristics for the MP dynamics. The MP charge $Q$ is determined by the MP potential $V_{d}$ with respect to the local sheath potential:

$$
Q(x)=C V_{d}(x) \text {, }
$$

where $C$ is the capacitance of the MP. If the MP radius is much smaller than the Debye length $\lambda_{D}=\left(\varepsilon_{0} T_{e} / n_{0} e^{2}\right)^{1 / 2}$ then the capacitance is

$$
C=4 \pi \varepsilon_{0}\left(1+a / \lambda_{D}\right) \approx 4 \pi \varepsilon_{0} a .
$$

The MP charging time depends on competition of different currents onto and from the MP surface. The steadystate potential to which a MP is charged is determined from the balance of particle currents to the grain:

$$
I_{i}\left(V_{d}\right)+I_{s e}\left(V_{d}\right)+I_{i-e}\left(V_{d}\right)+I_{e-e}\left(V_{d}\right)=0
$$

where $I_{i}$ is the ion current, $I_{s e}$ is the current of fast secondary electrons emitted from the substrate, $I_{i-e}$ is the secondary electron current from the MP surface caused by the impact of ions, $I_{e-e}$ is the current of secondary electrons emitted from the MP surface due to fast electron bombardment.

We calculate the currents $I_{i}$ and $I_{e}$ to the MP surface by using the orbital motion limited (OML) approach [15]. For $V_{d}<0$

$$
\begin{gathered}
I_{i}=\pi a^{2} j_{i}\left(1-\frac{2 Z e V_{d}}{m_{i} u_{i}^{2}}\right), \\
I_{s e}=\pi a^{2} j_{s e}\left(1+\frac{2 e V_{d}}{m_{e} u_{e}^{2}}\right), \\
I_{i-e}=(\gamma / Z) I_{i}, \\
I_{e-e}=\delta I_{e},
\end{gathered}
$$


where $u_{i}$ is the ion velocity, $u_{e}$ is the velocity of secondary electrons; $I_{i}=0$, if $2 Z e V_{d} / m_{i} u_{i}{ }^{2}>1$; and $I_{e}=0$, if $2 e V_{d} / m_{e} u_{e}^{2}<1$.

The secondary electron yield $\delta$ is described by Sternglass's universal curve [16]

$$
\delta=7.4 \cdot \delta_{m} \cdot \frac{\varepsilon_{e}}{\varepsilon_{e m}} \operatorname{Exp}\left(-2 \sqrt{\frac{\varepsilon_{e}}{\varepsilon_{e m}}}\right),
$$

where $\varepsilon_{e}$ is the primary electron energy, and $\varepsilon_{e m}$ is the energy for which the secondary yield $\delta_{m}$ is maximum.

In the case of PIII, the value of the SEE yield $\delta$ is comparable with value of the SEE yield $\gamma$.

\section{RESULTS AND DISCUSSION}

The model described above is applied to the case of titanium cathodic arc plasma used for PIII. The specific plasma parameters are taken as typical values from experiments: the electron temperature is $T_{e}=1 \mathrm{eV}$, the plasma bulk density is $n=10^{16} \mathrm{~m}^{-3}$, mean initial kinetic energy of ions is $\varepsilon_{i}=54 \mathrm{eV}$, mean ion charge is $Z=2$.

Using substrate bias of about $-1 \mathrm{kV}$, the energy of titanium ions with $Z=2$ at the substrate surface is of at least 2 $\mathrm{keV}$. The resulting ion energy for substrate bias $V_{0}=-2 \mathrm{kV}$ is of at least $4 \mathrm{keV}$. For these values of substrate bias KEE is dominant.

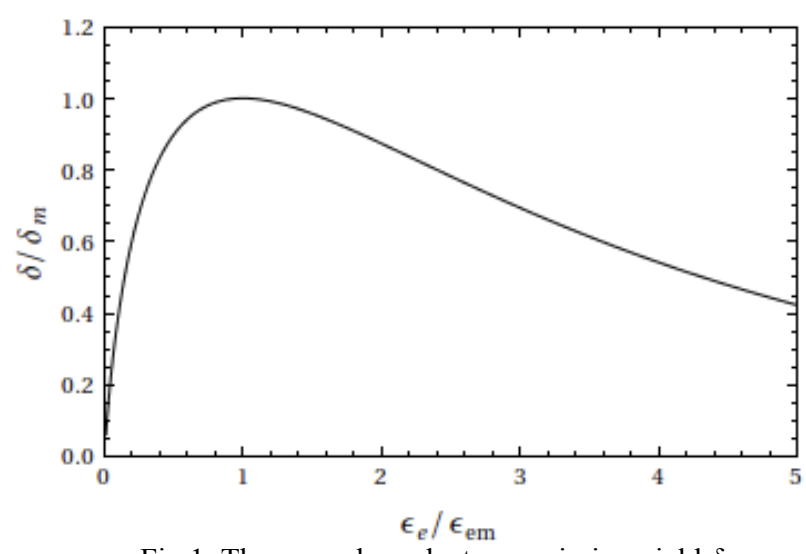

Fig.1. The secondary electron emission yield $\delta$

The secondary electron emission yield $\delta$ for electron impact on a solid as a function of primary electron energy

To begin with, one needs to know the SEE coefficients. The expression (22) makes it possible to find the SEE yield $\delta$ as a function of the energy of incident electrons $\varepsilon_{e}$ (Fig. 1). Titanium has $\delta_{m}=0.83$ and $\varepsilon_{e m}=300 \mathrm{eV}$. The SEE yield $\delta$ depends strongly on the electron energy, which reaches a maximum value at the sheath edge and a minimum value at the substrate. The substrate voltage bias provides the upper limit to the coefficient $\delta$. The measured total SEE yield $\gamma$ is presented in Ref. [9]. For an accelerating substrate bias $V_{0}=-6 \mathrm{kV}$, SEE yield $\gamma$ is about 2.7. Therefore, knowing that $\gamma \sim\left(V_{0}\right)^{1 / 2}$, the corresponding SEE yields $\gamma$ for substrate bias $V_{0}=-1 \mathrm{kV}$, and $-2 \mathrm{kV}$, are equal 1.1, and 1.6, respectively.

Equation (11) is numerically integrated to give the dependence of the potential distribution $\Phi(x)$ within the sheath on the normalized coordinate $z=x / \lambda_{D}$. Numerical solutions of (11) with (18)-(21) allow to determine the MP charge as a function of the MP position $z$ for given sheath potential profile $\Phi(x)$. The profile of MP charge for different values of substrate bias is shown in Fig. 2.

The negative MP charge is caused by higher current density of secondary electrons from the substrate than that of ions. An increase in substrate bias leads to larger absolute values of negative MP charge. The negatively charged MP is decelerated by electric field of the sheath. That is why for large repulsive field, MP cannot reach the substrate.
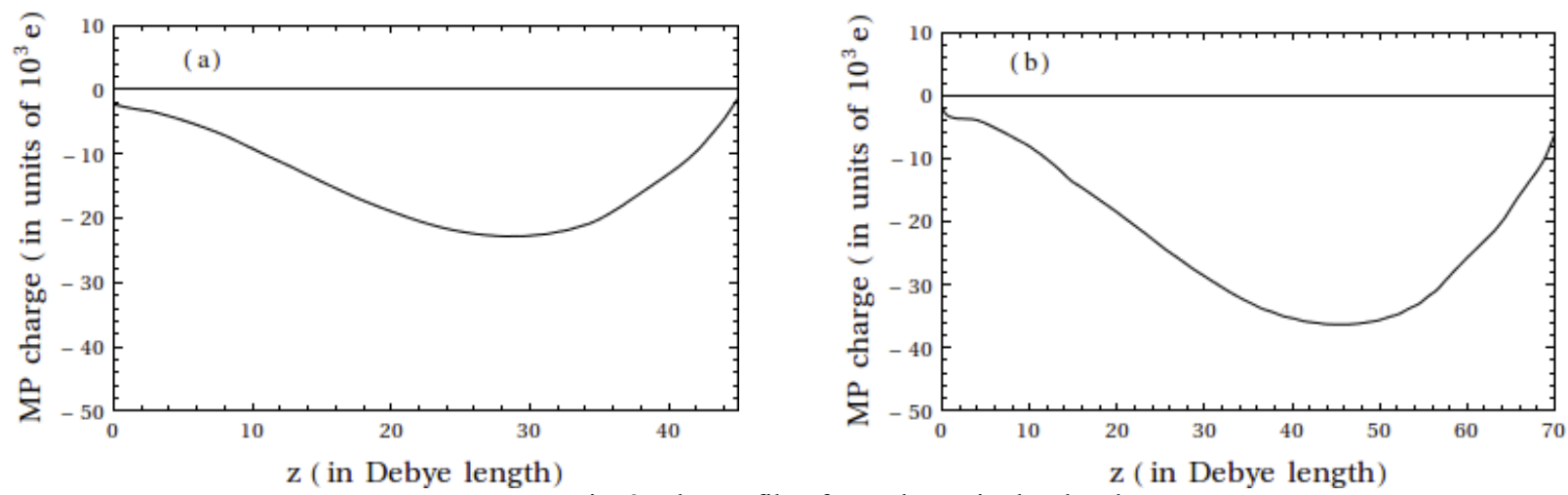

Fig. 2. The profile of MP charge in the sheath

The dependence of the charge of the MP of radius $0.25 \mu \mathrm{m}$, on the MP position $\mathrm{z}$ for different substrate biases: (a) $-1 \mathrm{kV}$, (b) $-2 \mathrm{kV}$ 


\section{CONCLUSION}

SEE is relevant for charging of MP in the near-substrate plasma. The substrate biasing directly influences the release of secondary electrons from the substrate because the KEE is dependent on the kinetic energy of the incident ions. In implantation sheath, KEE from the substrate contributes to the MP charging more significantly as compared with emission from MP surface due to high voltage bias of the substrate. The obtained results are in good agreement with the experimental data. PIII is demonstrated to be controllable technique for modification of surface without MPs.

\section{ORCID IDS}

Elena V. Romashchenko https://orcid.org/0000-0001-7815-8172,

D Aleksander A. Bizyukov https://orcid.org/0000-0003-0192-5219

(DIgor O. Girka https://orcid.org/0000-0001-6662-8683

\section{REFERENCES}

[1] R.L. Boxman, P.I. Martin and D.M. Sanders, editors, Handbook of vacuum arcs science and technology: fundamentals and applications (Noyes Publications, New Jersey, 1995), pp. 737.

[2] A. Anders, editor, Handbook of plasma immersion ion implantation and deposition (John Wiley \& Sons, New York, 2000), pp. 736.

[3] I.I. Beilis, IEEE Trans. Plasma Sci. 29(5), 657-670 (2001), https://doi.org/10.1109/27.964451.

[4] G.Yu. Yushkov, A.Anders, E.M. Oks and I.G. Brown, J. Appl. Phys. 88(10), 5618-5622 (2000), https://doi.org/10.1063/1.1321789.

[5] E.M. Oks, IEEE Trans. Plasma Sci. 30(1), P. 202-207 (2002), https://doi.org/10.1109/TPS.2002.1003861.

[6] R.L. Boxman and S. Goldsmith, Surf. Coat. Technol. 52, 39-50 (1992), https://doi.org/10.1016/0257-8972(92)90369-L.

[7] C.N. Tai, E.S. Koh and K. Akari, Surf. Coat. Technol. 43/44, 324-335 (1990), https://doi.org/10.1016/0257-8972(90)90085-Q.

[8] A.A. Bizyukov, I.O. Girka and E.V. Romashchenko, IEEE Trans. Plasma Sci. 44(7), 1050-1056 (2016), https://doi.org/10.1109/TPS.2016.2573284.

[9] A. Anders, Cathodic arcs: from fractal spots to energetic condensation, (Springer, New York, 2008), pp. 540.

[10] M.A. Lieberman, J. Appl. Phys. 66(7), 2926-2929 (1989), https://doi.org/10.1063/1.344172.

[11] S. Qin, C. Chan and Z. Jin, J. Appl. Phys. 79(7), 3432-3437 (1996), https://doi.org/10.1063/1.360640.

[12] M.A. Lieberman and A.J. Lichtenberg, Principles of plasma discharge and material processing, (John Wiley\&Sons, New York, 2000), pp. 299.

[13] A. Anders, Surf. Coat. Technol. 136(1-3), 85-92 (2001), https://doi.org/10.1016/S0257-8972(00)01017-3.

[14] I.G. Brown, O.R. Monteiro and M.M.M. Bilek, Appl. Phys. Lett. 74(17), 2426-2428 (1999), https://doi.org/10.1063/1.123869.

[15] I. Langmuir, in: Collected Works of Irving Langmuir, edited by G. Suits (Pergamon, New York, 1961).

[16] E.J. Sternglass, The theory of secondary electron emission, (Westinghouse Res. Lab. Sci. Pap,Pittsburgh, 1954).

\section{ВІДБИТТЯ МАКРОЧАСТИНКИ ВІД ЗАРЯДЖЕНОЇ ПІДКЛАДКИ У ПЛАЗМОВИХ СИСТЕМАХ ІОННОЇ ІМПЛАНТАЦІЇ \\ О.В. Ромащенко, О.А. Бізюков, І.О. Гірка \\ Харківський національний університет імені В. Н. Каразіна \\ м. Свободи, 4, 61022, Харків, Україна}

Генерація металевої плазми у вакуумно-дуговому розряді завжди супроводжується виробництвом макрочастинок (МЧ). Забруднення поверхонь МЧ є найбільш важливою технологічною проблемою при плазмовій імерсійній імплантації іонів (ПIII). Результати теоретичного дослідження заряджання та динаміки МЧ у плазмовому шарі представлено для випадку ПІІІ з імпульсами довгої тривалості. Для опису заряджання МЧ у шарі теоретичну модель шару поєднано з теорією обмеженого орбітального руху (ООР). Заряджання МЧ у шарі досліджено з урахуванням як емісійних процесів з поверхні МЧ, так і кінетичної електронної емісії (КЕЕ) з підкладки 3 високим потенціалом зсуву. Заряд і динаміка МЧ визначаються локальними параметрами протилежних потоків іонів та вторинних електронів з підкладки. Заряд МЧ залежить від положення МЧ усередині шару. Показано, що домінуючу роль у заряджанні МЧ відіграє КЕЕ з підкладки, яка є важливою властивістю ПІІІ. КЕЕ з підкладки змінює профіль потенціалу усередині шару, товщину шару та баланс струмів на поверхню МЧ. Отримано, що МЧ заряджається негативно внаслідок того, що густина струму вторинних електронів 3 підкладки є більшою за густину струму іонів. Це можливо, коли коефіцієнт КЕЕ більший за одиницю. Застосування негативного потенціалу зсуву до підкладки впливає на виривання вторинних електронів 3 підкладки іонами та на їх прискорення у шарі. Отримано, що збільшення негативного зсуву потенціалу підкладки призводить до збільшення абсолютної величини негативного заряду МЧ, та таким чином, до збільшення електростатичного відбиття МЧ від підкладки. Показано, що застосування негативного потенціалу зсуву до підкладки є ефективним альтернативним засобом зменшення забруднень МЧ покриттів без застосування магнітних фільтрів.

КЛЮЧОВІ СЛОВА: плазмова імерсійна імплантація іонів, макрочастинка, кінетична електронна емісія

\section{ОТРАЖЕНИЕ МАКРОЧАСТИЦЫ ОТ ЗАРЯЖЕННОЙ ПОДЛОЖКИ В ПЛАЗМЕННЫХ СИСТЕМАХ ИОННОЙ ИМПЛАНТАЦИИ Е.В. Ромащенко, А.А. Бизюков, И.А. Гирка}

Харьковский национальный университет имени В. Н. Каразина пл. Свободы, 4, 61022, Харьков, Украина

Генерация металлической плазмы в вакуумно-дуговом разряде всегда сопровождается производством макрочастиц (МЧ). Загрязнение покрытий МЧ является наиболее важной технологической проблемой при плазменной иммерсионной имплантации ионов (ПИИИ). Результаты теоретического исследования зарядки и динамики МЧ в плазменном слое 
представлены для случая ПИИ с импульсами большой длительности. Для исследования зарядки МЧ в слое теоретическая модель слоя скомбинирована с теорией ограниченного орбитального движения (ООД). Зарядка МЧ в слое изучена с учетом как эмиссионных процессов с поверхности МЧ, так и с учетом кинетической электронной эмиссии (КЭЭ) с подложки с высоким потенциалом смещения. Заряд и динамика МЧ определяются локальными параметрами встречных потоков ионов и вторичных электронов с подложки. Заряд МЧ зависит от положения МЧ в слое. Показано, что доминирующую роль в зарядке МЧ играет КЭЭ, которая является важной особенностью ПИИИ. КЭЭ с положки изменяет профиль потенциала внутри слоя, толщину слоя и баланс токов на поверхность МЧ. Получено, что МЧ заряжается отрицательно вследствие того, что плотность тока вторичных электронов с подложки больше, чем плотность тока ионов. Это возможно, когда коэффициент КЕЕ больше единицы. Приложение отрицательного потенциала смещения к подложке влияет на вырывание вторичных электронов из подложки ионами и на их ускорение в слое. Получено, что увеличение отрицательного потенциала смещения подложки приводит к увеличению абсолютной величины отрицательного заряда МЧ, и тем самым, к увеличению электростатического отражения МЧ от подложки. Показано, что применение отрицательного потенциала смещения к подложке является эффективным альтернативным методом уменьшения загрязнения покрытий МЧ без применения магнитных фильтров.

КЛЮЧЕВЫЕ СЛОВА: плазменная иммерсионная имплантация ионов, макрочастица, кинетическая электронная эмиссия 